\title{
Spiritual Care of the III and the Dying in First Pastoral Theology Textbooks (Rautenstrauch, Giftschütz, Chládek, Stach) ${ }^{1}$
}

\section{Zdeněk Duda}

Care of the ill and the dying, which independently of theological expositions and social conditions has always belonged to the basic acts of practical realization of Christian life, underwent major change in the second half of the $18^{\text {th }}$ century due to an overall change of climate in the society of the European West. New ways and procedures of thought, in the centre of which there was the human being and the concept of progress, enlightenment and happiness, that we have got accustomed to call the Enlightenment, affected all areas of social life, among others the social, cultural and religious one. The new thinking was attractive especially for the worldly authorities, who strove to fortify their power by means of socalled enlightened reforms, frequently shielded by a formula of general welfare. Sources of inspiration in the religious sphere were, beside the broad concept of Enlightenment, Jansenist and other ideas, which together brought a new conception of piety and religious life as such.

Piety and religious dealing with death were also influenced by new attitudes to death and the requirement of new priestly action on the dying and the bereaved. ${ }^{2}$ Care of the ill and the dying received new incentives and emphases, its ideal and obligatory form was being defined and systematized. ${ }^{3}$ This occurred, among others, in pastoral theology textbooks. ${ }^{4}$ The very subject field of pastoral theology was a newly constituted part of the canon of theological disciplines and a new university subject. ${ }^{5}$

The aim of this study is, based on analysis of the first study texts of the subject of pastoral theology and the context in which they were being written, to describe the fundamental points of departure, procedures and appearance of spiritual care of the ill and the dying that was as ideal and obligatory presented to future Catholic spiritual administrators as part of university education. ${ }^{6}$ The study is based primarily on two study texts that received broader use in the Czech milieu. ${ }^{7}$ Pastoral theology was to be taught in the students'

1 This paper was written as part of the project of specific research GAJU 096/2015/H - Pastoral care of the ill and the dying at the end of the 18th century.

2 Cf. Zdeněk R. NEŠPOR, Demonstrace konfesionality prostřednictvím pohřebních rituálů v českých zemích po vydání Tolerančního patentu, in: Církev a smrt. Institucionalizace smrti v raném novověku, ed. Martin HOLÝ - Jiří MIKULEC, Praha: Historický ústav, 2007, p. 286.

3 On the history of pastoral care of the ill cf. e.g. Gottfried ROTH - Hansjörg SCHILD, Das Phänomen der Krankheit und der Kranken in der Kirche, in: Handbuch der Pastoraltbeologie, Bd. 4, Freiburg: Herder, 1969, pp. 178-193.

4 Cf. Zdeněk DUDA, Nemoc a smrt v opatrné péči osvícenského pastýře. K dějinám pastorace nemocných a umírajících na konci 18. století optikou první české učebnice pastorální teologie, in: Jednota v mnobosti - Olomonc 2014, Fórum Velebrad X., Olomouc: Refugium, 2015, pp. 59-66.

5 Cf. Alois KŘIŠT̃AN, Počátky pastorální teologie v českých zemích, Praha: Triton, 2004. Further cf. Zdeněk DUDA, Historiografický obraz počátků (české) pastorální teologie a jejího dalšího směřování v 19. století, in: Církve 19. a 20. století ve slovenské a české bistoriografii, ed. Pavol MAČALA - Pavel MAREK - Jiří HANUŠ, Brno: Centrum pro studium demokracie a kultury, 2010, pp. $18-20$.

6 The obligatory tabular pattern of the new subject of pastoral theology worked with the concept of spiritual care of the ill, the other texts analysed here with the concept of visiting the ill.

7 Cf. Kamil ČINÁTL, Katolické osvícenství a koncept pastorální teologie, Kuděj 2/2000, p. 31. 
native language, in our lands therefore in German and in Czech. The first Czech-language textbook, and one of the very first textbooks on the new subject, was the book by the Strahov Premonstratensian Jiljí Chládek, published in Prague in 1780-1781 under the title Proemia to Shepherdly Care. ${ }^{8}$ The second and here similarly analysed text was the Czech translation of the at the time most successful and officially prescribed textbook by the Viennese pastoral theologian Franz Giftschütz, ${ }^{9}$ translated to Czech from the second edition of 1787 by the Olomouc professor Václav Stach under the title Proemia to Shepherdly Theology. ${ }^{10}$

\section{Reform of theological study and obligatory curriculum of the new discipline of pastoral theology}

The first study texts of the new discipline of pastoral theology were written according to the tabular pattern of this discipline (1778), intended as systematic treatment and introduction to the practical performance of the clerical vocation. The pattern, authored by the creator of the new conception of theological study, the Břevnov abbot František Štěpán Rautenstrauch, ${ }^{11}$ was confirmed by the power of courtly decrees. It thus became an obligatory norm. ${ }^{12}$ The state intervention was no accident, as in the second half of the 18th century enlightened monarchs claimed ever greater influence on the preparation of future clerics.

A vital reform of theological study took place in the Danube monarchy in mid 1770s. The reform, carried out in a Jansenist-enlightened spirit, had pragmatic goals, strongly practiceoriented. It also met the contemporary requirements on systematization, a new order and place was impressed on the spheres of theological thought. Theology and the preparation of clerics were subjected to a practical pastoral intention. ${ }^{13}$ Future priests were being prepared for the role of administrators of the clerical office, administration and the fulfilment of three main official obligations was to become the object of their activity. Their task was to teach, sanctify and advance piety. The means of preparation for orderly execution of these obligations was primarily the newly introduced discipline of pastoral theology.

8 Jiljí (Aegidius) Chládek (1743-1806) was a Premonstratensian religious canon, since 1778 professor of Czech pastoral theology at the Prague theological faculty. He also served as dean of the faculty (1792-1793) and university rector (1794) and as censor of religious literature. Cf. Jiljí CHLÁDEK, Počátkové opatrnosti pastýršsé aneb krátká naučení, jak by se pastýrové duchovní v povoláni svém chovati mèli, I-III, Praha, 1780-1781.

9 Franz Giftschütz (1748-1788) was active first as cleric at St. Stephen in Vienna, in 1778 he became professor of pastoral theology at the Vienna theological faculty. His textbook of pastoral theology Leitfaden für die in den k.k. Erblanden vorgeschriebenen deutschen Vorlesungen über die Pastoraltheologie was the most successful study text on the subject at the time. It was printed in five editions (1785, 1787, 1796, 1801, 1811), translated also to Latin and Czech.

10 Václav Stach (1754-1831) was professor of pastoral theology in the general and episcopal seminary in Olomouc, pensioned in 1799. He is also mentioned as a representative of popular education efforts in the spirit of Josephine enlightenment and in connection with the origins of modern Czech poetry. In 1787 he published the well-known Handbook of the People's Teacher. Cf. Franz GIFTSCHÜTZ, Počátkové k verejnému v cís. král. zemích předepsanému vykládání pastýřské teologie, I-II, Praha, 1789-1790.

11 František Štěpán Rautenstrauch (1734-1785) was abbot of the double abbey Broumov-Břevnov since 1773 and also director of the theological faculty in Prague, later in Vienna. He was strongly influenced by Jansenist-enlightened thought, was one of the most convinced proponents of (Josephine) reforms. In 1782 he was appointed counsellor in the Czech-Austrian Courtly Office and member of the courtly spiritual commission. He belonged in the monarch's closest circle of counsellors. He proposed and set through a reform of theological study. He was also commissioned to set up episcopal general seminaries.

12 Rautenstrauch's Tabellarischer Grundriß der in der deutscher Sprache vorzutragenden Pastoraltheologie is published and written out e.g. in the collection of texts Wege der Pastoraltheologie: Texte einer Bewusstwerdung. I. 18. Jabrbundert: Grundlegung und Entfaltung, ed. Anton ZOTTL - Werner SCHNEIDER, Eichstätt: Franz Sales Verlag, 1987, pp. 27-34. On that cf. the Czech translation Alois KŘIŠŤAN, Počátky, pp. 54-62.

13 Cf. Josef MÜLLER, Zu den theologiegeschichtlichen Grundlagen der Studienreform Rautenstrauchs, Tübinger Theologische Quartalschrift 146/1966, pp. 62-64. 
The obligatory curriculum of the new subject, which was subsequently developed and concretized in the newly created study texts of the practice-oriented subject, worked with a concept of priesthood in which direct bond to the supernatural Revelation was markedly weakened. On the contrary, in consisted of contents having to do with activities oriented at this world and pertained to education, morals and general welfare. Unlike the Tridentine ideal of the pious angelic priest-sacrificer, the cleric was now much rather perceived as a person of dual function, fundamentally as servant of the Church and derivatively as servant of the state, a clerk obliged to work in the field of salvation, state administration and happiness immanent to the world. ${ }^{14}$

The priest as spiritual administrator was the only subject of this (clerical) administration, the only person authorized to act and solve pastoral issues. The contents of pastoral work were teaching, admonishing, punishing, comforting, administering sacraments and building up the parish community. Pastoral work was a one-way activity, it went from the office of the spiritual administrator to the individual parishioners and the whole parish community. The only subject of acting in the field of pastoral care was the spiritual administrator; lay persons and the parish community were the object of appropriate informed care.

The tabular pattern of the new discipline divided the object of study into four larger wholes. The first introductory part, bringing an overview of basic terminology including the pastoral office and pastoral theology, was followed by three thematic areas corresponding to the three main duties of the spiritual shepherd. Care of the ill and dying was subsumed under the section on the duty of administration and administering sacraments.

As in the case of the other two main duties of the clerical office administrator, the duty of administration and administering sacraments was also assigned a biblical foundation. It was referred to the words of commissioning (Mt 28:19-20). Although these directly concern baptism, derivatively they were to comprise the other sacraments as well. The thematic exposition of the duty of administration and administering sacraments was to be structured in the future textbooks into seven parts according to the number of sacraments. In that it was to take note only of administering sacraments proper, the dogmatic element was left to dogmatic theology, the teaching on the requirements laid on the recipient of sacraments to theoretical moral theology. Three identical areas were to be introduced separately for each part, pertaining to the recipients of sacraments, preparation of the recipients, and rituals and rites accompanying the administration. The basis was to be the ritual of the particular episcopate, to which the doctrine of rituals and rites was to conform.

Special note was taken of three so-called most important and most difficult matters brought up in elaborating the topic of sacrament of penance, extreme unction and matrimony.

14 Cf. Rudolf ZUBER, Osudy moravské církve v 18. století, II. díl, Olomouc: Matice cyrilometodějská, 2003, esp. p. 85; 150-152. On the reform of theological study, the contemporary concept of priesthood and context of contemporary theology cf. also Hedvika KUCHAŘOVÁ - Zdeněk R. NEŠPOR, Pastor bonus, seu idea (semper) reformanda. Vzdělávání a výchova kléru pro působení ve farní správě v českých zemích v 18. a na počátku 19. století, Český časopis bistorický 2/2007, pp. 351-392; Konrad BAUMGARTNER, Der Wandel des Priesterbildes. Beiträge zur pastoraltheologischen Literatur vor Allem des 17. und 18. Jahrhunderts, in:

Pastoraltheologie: Ein entscheidender Teil der josephinischen Studienreform: Ein Beitrag zur Geschicbte der praktischen Theologie, ed. Ferdinand KLOSTERMANN - Josef MÜLLER, Wien: Herder, 1979, pp. 174-186; Zdeněk DUDA, Obraz katolickébo duchouníbo v proních učebnicích pastorální teologie (Giftscbütr, Cbládek, Stach), v tisku. 
In particular this entailed the doctrine of the confessional and the offices of the confessor (judge, teacher and healer of souls), "the most important spiritual care of the ill" and practical issues linked to contracting marriage (impediments, invalidity, revalidation, dispensation). ${ }^{15}$ The conclusion of the part devoted to the duty of administration and administering sacraments was to be devoted to a treatment of prayer and the sacrifice of holy mass by the spiritual administrator for the entrusted community.

The layout of the curriculum of pastoral theology clearly shows that its creator ascribed great importance to pastoral care of the ill and the dying. Further, it was a novelty at the time. Due to medicalization processes and Jansenist-enlightened efforts the concept of illness had gained importance, it became a place where it was still possible to operate with earthly happiness and at the same time think of the eternal one. Spiritual care of the ill replaced, filled and relabelled the traditional Christian preparation for a good death. Abbot Rautenstrauch regarded it as one of the most difficult and at the same time most important spheres of the practically oriented activities of a spiritual shepherd. He recommended treating it in the part devoted to the sacramental practice of the Church, though he was aware that it was a much broader area. It was similar in the case of care of convicted persons, also to be addressed here, for which it also held that administering sacraments is only its small part.

The importance ascribed at that time to spiritual care of the ill is also testified by the fact that the spiritual shepherd's speech at the bedside of an ill person was, beside other practical knowledge and skills, fundamentally delivering sermons and teaching catechism, was part of the parish competition examination which, according to an ordinance of January 1782 and then a series of other courtly decrees, had to be taken by all applying for a parish. ${ }^{16}$

\section{Position and points of departure of spiritual care of the ill and the dying in textbooks by Jiljí Chládek and Franz Giftschütz}

Rautenstrauch's tabular pattern was followed by all prepared study texts. The pattern presented the obligatory outline, the particular contents could be grasped in a creative manner. Further needs and wishes of the state power were also reflected in the textbooks to various extent. The textbook of the Viennese pastoralist Franz Giftschütz was model in this respect, since in its second edition it referred to almost two hundred (174) state ordinances. ${ }^{17}$ This was also the reason why it was markedly successful and popular at the court. Already in its first edition it was prescribed as the general and obligatory textbook for teaching pastoral theology throughout the monarchy. It this position it was replaced only in

15 Cf. "With the sacrament of extreme unction the whole practice of the most important spiritual care of the ill must be taught. It is also especially important to lecture on the behaviour of the shepherd to condemned criminals." Quoted according to the Czech translation Alois KŘIŠŤAN, Počátky, p. 59.

16 Parish priests who had proved especially competent in the so-called office of spiritual administration and could prove it with a certificate could be nominated to another parish without taking the parish competition examination. The speech of the spiritual administrator at the bedside of the ill was set as part of the examination by a decree of February $9^{\text {th }}, 1784$. Cf. Eduard WINTER, Josefinismus a jeho dějiny. Přispěvky k duchovním dějinám Čech a Moravy 1740-1848, Praha: Nakladatelství Jelínek, 1945, pp. 132-133. 17 Cf. Gustav PIRICH, Franz Giftschütz (1748-1788) - der erste Wiener Pastoraltheologe. Theologische Grundlinien in Leben und Werk unter dem Einfluß des Jansenismus, der katholischen Aufklärung und des Ultramontanismus, Würzburg: Seelsorge/Echter, 1992, pp. 172-173. 
1812 by the study text of Andreas Reichenberger. ${ }^{18}$ Rautenstrauch's pattern was of course followed also by the two "Czech" textbooks, Stach's translation of Giftschütz's successful Leiffaden and the original study text by Jiljí Chládek.

Chládek's textbook was structured in accordance with the recommended curriculum. It was highly critical of the contemporary practice of the Church. In the first part the history of pastoral theology was briefly introduced, Czech preachers were also mentioned, the Czech Brethren received some sympathy. Then the issues of teaching, general principles, homiletics, private teaching were treated. Emphasis was laid on individual action of the spiritual administrators on the people in the parish and on the method of conversation. Tolerant attitude to other faith adherents and non-believers was expressed. In the second part devoted to the topic of sacrament administration, penance was accentuated as the only source of the rectification of a sinner, whereby the institute of indulgencies was critically viewed, as well as Jesuit confessional practice. The topic of the third part was the exemplary life of shepherds, it was probably the most critical part of the textbook. The priest was presented here not only as expert in religious and spiritual life, but also as warrantor of legal safety and security of the people in his parish, e.g. as advocate of subjects with respect to injustice on the part of the authorities. ${ }^{19}$ Chládek viewed the cleric as a good shepherd, teacher of morality. Significant in this respect was the scene on the title page of his textbook, where the good shepherd was finding the lost sheep.

By a courtly decree of November 1780 Chládek's text was accepted as university textbook. It was prescribed for Prague and Brno. From the very beginning it was subject to sharp criticism and rejection. The author was bombarded with reproofs and insults, accused of betraying the priestly state, suspected of heresy. The Olomouc professor Václav Stach allegedly ridiculed Chládek's text at his lectures attended by an inspection of the courtly committee and thanks to that was commissioned to translate Giftschütz's textbook favoured by the court. ${ }^{20}$ That, however, was in many respects much more radical and more rigorous, in a certain sense better and more rationally structured. In the Josephine spirit it also regarded the cleric as an official of the state, who was to look after spiritual matters, supporting general welfare. It expressly presented moral doctrine as the main contents of the gospel, dogmatic precepts were only perceived as an accompanying hang-on. ${ }^{21}$ It linked the topic of salvation as eternal happiness with earthly happiness and subordinated it to the requirement of moral life; it almost became a function of morality. Stach's translation, printed under the title Počátkové pastýřské teologie in Prague in 1789-1790, soon replaced Chládek's textbook. ${ }^{22}$

In Chládek's textbook care of the ill and the dying was, according to Rautenstrauch's intentions, set in the context of sacramental practice of the Church and treated in the sixth chapter of the second volume, called $O n$ the sacrament of extreme unction. The chapter was divided into three sections. The first and most extensive was devoted to visiting and providing

18 Cf. ibid, pp. 132-134.

19 Cf. Jan HARVILKO, Jiljí Chládek a jeho počátkové opatrnosti pastýřské, Theologická revue 1-4/2006, pp. 382-383.

20 Cf. Alois KŘIŠŤAN, Počátky, p. 92 and further František CINEK, K národnímu probuzení moravskébo dorostu kně̌̌skébo 1778-1870, Olomouc: Družina literární a umělecká, 1934, pp. 71-72.

21 Cf. Franz GIFTSCHÜTZ, Leitfaden für die in den k.k. Erblanden vorgeschriebenen deutschen Vorlesungen über die Pastoraltheologie, Wien, 1787, p. 35.

22 Cf. Alois KŘIŠŤAN, Počátky, p. 92. 
for the ill, the second briefly noted the sacrament of extreme unction, the third concluding section proposed a manner of dealing with persons condemned to death. ${ }^{23}$ Administering the sacrament of extreme unction, or the last three sacraments, which had formerly been the contents of the traditional Christian preparation for good death, as witnessed for example by the rich literature of artes moriendi books, was here but a part of broader spiritual care of the ill. To this of course belonged care of the dying, since the lightest illness could at that time still almost always turn to death.

Stach's, in fact Giftschütz's, textbook further weakened the relationship between sacramental practice of the Church and spiritual care of the ill. It seems as if administering the sacrament of extreme unction was not even a (necessary) part of this care. Giftschütz did not follow Rautenstrauch's recommendation and treated spiritual care of the ill already in the third part of the first volume of his textbook. ${ }^{24} \mathrm{He}$ incorporated it in a chapter devoted to private teaching, viz. the spiritual administrator's role to take care that each parishioner could according to his needs, state and possibilities be introduced to the Christian doctrine and apply this doctrine to his advantage in his life. ${ }^{25}$

In the author's view, spiritual care of the ill was primarily help to persons in a special situation, to whom it was necessary to provide the needed and to their state appropriate comfort and advice. Similar special private care was, besides the ill, to be provided to fiancés and others. The spiritual shepherd was to serve the people in his parish by advice and example and not to omit any opportunity to be beneficent. Such opportunity was also illness and the accompanying difficulties, hence the spiritual shepherds' duty to visit the ill. The goals of spiritual care of the ill corresponded to the goals of (private) teaching, which was to serve the edification and betterment of the persons concerned and generally the increase and fortification of the happiness of the entrusted people. ${ }^{26}$

Giftschütz's approach to care of the ill and the dying was strongly pragmatic and assumed practically oriented piety. All activity was to be rid of superstitions and purposeless and pointless habits and rites and have a logical and rational justification. However, in all that he had the good of man in mind. But that man was, as also in Chládek, a man with a nonspecific face, the obedient and grateful object of informed care. The point of departure was the goal of this care, the contents were a dependent variable of the Enlightenment concept of happiness and state administration, (religious) reasoning was a self-contained jigsaw puzzle. Into the logically ordered system suitable justifications were inserted to confirm already formed views and required patterns of behaviour, often in the form of biblical quotations. ${ }^{27}$ That, however, was a traditional and common manner, not only at that time.

Cf. Jiljí CHLÁDEK, Počátkové, II. dúl, pp. 152-203.

Cf. Franz GIFTSCHÜTZ, Počátkové, I. díl, pp. 233-256.

Cf. ibid, p. 182.

Cf. ibid, p. 184.

7 On the use of biblical quotations in the textbook of the Viennese pastoralist cf. Gustav PIRICH, Franz Giftschütz, p. 196. 


\section{The (Sacramental) Rite of Extreme Unction}

In the second volume of Giftschütz's textbook, in the part devoted to sacramental practice of the Church, future spiritual administrators were introduced to the fact that in the Catholic Church there exists, with reference to the Epistle of James (Jas 5:14), a rite of performing prayers over the seriously ill, with which multiple anointing is linked. This rite was to be called anointing of the ill or also extreme unction. ${ }^{28}$ The practice of the Church in this activity follows a biblical model. Giftschütz only formally allocated it to the section on administering sacraments, but intentionally did not use the term sacrament. The translator Václav Stach also kept a restrained attitude, he also avoided the concept of sacrament. ${ }^{29}$

For the particular course and form of administering this "rite" the author of the textbook referred the theological students in everything to the relevant (Viennese) diocesan ritual, which he abundantly quoted in the notes. This shows that he did not assign any special meaning to this "rite". He subordinated the issue of administering sacraments to the extant church tradition and left the dogmatic aspect aside. He only touched on several questions, recipients of the unction and their preparation, as the obligatory pattern required. $\mathrm{He}$ expressly mentioned that this unction is only for the ill, among whom he also counted very old people not suffering of any immediate illness. Sufficient "qualification" was very senile age. He also listed categories of those who could not receive the unction, always with relevant reference to the Viennese ritual. ${ }^{30}$

To the applicable diocesan ritual he also left the question whether the last unction was to be administered before or after "receiving the Lord's Supper" ${ }^{31}$ Chládek did not touch on this issue, he stated the order of the individual sacraments quite matter-of-factly, just as he did with the concept of sacrament. After confession receiving the Eucharist was to follow, and in case of need also the sacrament of extreme unction, or also granting plenary indulgence (general absolution) according to the ordinance of the Archbishop's Office of February $1750 . .^{32}$

It is significant that the pastoralist Giftschütz did not link administering the "rite" of extreme unction with spiritual care of the ill. The individual provisions stated in the first and second volume of the textbook shared only the effort that the spiritual shepherd coming to the ill not be perceived as a messenger of death. In that position he could neither care for the ill in an appropriate manner, nor administer extreme unction. Religious rituals were to have greater effect when the recipient as object of informed care could understand them well and

28 Cf. Franz GIFTSCHÜTZ, Leitfaden, pp. 161-164.

29 Cf. Franz GIFTSCHÜTZ, Počátkové, II. díl, pp. 144-147.

30 Cf. ibid, p. 146.

31 The structure and form of the prayers and the individual parts of this unction differed depending on whether it was administered before or after receiving the Eucharist. In the Roman ritual of 1614 (Rituale Romanum) anointing the ill was placed as the last of the last three sacraments and thus became extreme unction in full sense of the word. Cf. Benedikt KRANEMANN, Die Krankensalbung in der Zeit der Aufklärung. Ritualien und pastoralliturgische Studien im deutschen Sprachgebiet, Münster: Aschendorffsche Verlagsbuchhandlung, 1990, pp. 126-133.

32 Cf. Jiljí CHLÁDEK, Počátkové, II. díl, pp. 164-171. Further cf. Eduard BRYNYCH, Generální absoluce umírajících čili Požehnání apoštolské v dobu smrti, Časopis katolického duchovenstva 8/1880, pp. 582-595. 
perceive their meaning. For practical reasons the spiritual shepherds were therefore at every occasion to instruct their parishioners on their role in the parish community. ${ }^{33} \mathrm{~A}$ similar recommendation, as well as the already traditional criticism of delaying the priest's visit at the bedside of the ill until the hour of death, appears also in Chládek. ${ }^{34}$

\section{The forms and goals of spiritual care of the ill and the dying}

In the spirit of enlightened anthropocentrism spiritual care of the ill in Giftschütz's textbook was based on differentiated and individualized approach to the ill. ${ }^{35}$ The goals were the same, the particular form differed according to social status, religion and kind of illness. The care derived from the needs, state and possibilities of the ill, the spiritual administrator was required to know his parishioners well and be able to communicate well and decently with them, to win their confidence. The spiritual administrator was to consider the age, social status, property, family relations, religious faith and knowledge and observation of Christian morality, also seriousness of illness. According to that he was to know how best to deal with various kinds of the ill, how to be most beneficent to them. That required granting them appropriate comfort and instruction, admonition and rectification, all that in conversations and visits. Spiritual care of the ill in the absence of the sacramental dimension meant especially visiting the ill as such. ${ }^{36}$

In general the goals of spiritual care of the dying were identical to those of the activity of the spiritual administrator as a whole, i.e., comforting and rectification of the ill. ${ }^{37}$ In particular this meant a) to comfort the ill person and encourage him to patience and committing himself to the will of God, and b) to use the state of illness to a transformation of his mind, rectification and preparation for future life. In order to reach these goals it was necessary to choose different words and contents with individual categories of ill persons. In case of serious illness the goal of spiritual care was to prepare the dying person for consoled and peaceful expectation of death. ${ }^{38}$ Spiritual care of the ill could also mean an effort at healing, but only in very limited cases. The spiritual administrator typically was not an expert in the medical aspect, he was rather to step aside and avoid possible annoyances, gossip and squabbles with physicians. But as general friend of the people he was to intervene where a physician was lacking. The argument here was the biblical image of Christ, who often first healed the body and then the soul..$^{39}$

Healing also did not depend only on medical knowledge and skills, it was a gift, grace of God. Man was to learn that all he has comes from God and is granted to him, not only in

33 Cf. Franz GIFTSCHÜTZ, Počátkové, I. dill, pp. 233, 239; II. díl, p. 145.

34 Cf. Jiljí CHLÁDEK, Počátkové, II. díl, pp. 153-154.

35 The entire sphere of private teaching was similarly differentiated. Cf. Franz GIFTSCHÜTZ, Počáttové, I. díl, p. 230.

36 In one breath it was repeated, in the spirit of Rautenstrauch's view, that visiting the ill was one of the most important and also most difficult activities of the spiritual shepherd's office. Cf. ibid, p. 233.

37 Cf. ibid, p. 22.

38 Cf. ibid, p. 234.

39 The argument was similar in case of the question of the presence of the spiritual administrator at an operation, at the time always closely linked to danger of death. The presence of the spiritual administrator in this matter was useless, possibly indecent, he was not an expert in this. If the ill person wished so, the spiritual shepherd was to oblige him. Otherwise the spiritual shepherd fulfilled his role by preparing the ill person for the operation and possible death well and providing the necessary encouragement. Cf. ibid, pp. 234-235; 256. 
illness. Such knowledge required an attitude of gratitude and active cooperation in serving God, men and general welfare. ${ }^{40}$ The theological concept of grace as unmerited gift of divine love and mercy was quite commonplace in Giftschütz. ${ }^{41}$

Differentiated approach to the ill was also reflected in the clearly reserved attitude to (traditional) literature intended for ill persons. For enlightened Catholic scholars the contents of such books was often problematic, it often corresponded to a different and rejected conception of piety, which was most markedly apparent in topics closely related to death. The author of the textbook specifically mentioned the prayers contained in literature for the ill. These were to be either very general, or on the contrary too narrowly focused, which of course did not suit the individualized attitude to ill persons and rather gave rise to difficulties and troubles. A more fundamental reason was of course the fact that the best pious text could not encompass all requirements placed on spiritual care of the dying. ${ }^{42}$

With that the Viennese pastoralist assigned much importance to prayer. He saw in it a practical means of fortifying virtuous life and by transposition also of attaining eternal happiness. Prayer was to remind man of his origin and his subordination to divine and human power deriving from it. It was also to divert man from overt preoccupation with himself, whether motivated by pride or excessive grief and dejection. Prayer was also to help man at times when he had already received instruction and a weakness was falling over him. In any case it was to derive from the situation of the particular person, reflect his specificity and turn directly to God. One could pray alone, together with others, or also together with his spiritual shepherd. One could also pray for others, typically for the ill and the dying. When praying with ill persons the shepherd was to take care that the prayer is, besides the above characteristics, short and intelligible. ${ }^{43}$

Prayer was to have a practical goal. It was for example to help the dying person commend his soul to God. If the dying person was no longer conscious, carrying on with such prayer was pointless. Nonetheless, the near ones often requested it. For practical reasons it was both necessary and suitable to comply. The spiritual shepherd could use such an opportunity to instruct precisely those persons. They were to receive similar instruction in prayer when their state changed to the bereaved. ${ }^{44}$ Behind such view of the concept of prayer one must see the context of the contemporary theological thinking as well as Giftschütz's effort to link the concept of eternal happiness with the concept of earthly happiness. ${ }^{45}$

The conception of spiritual care of the ill in the first Czech textbook of pastoral theology was different to a certain extent. In his lecture notes Professor Chládek presented a unified ideal manner of care for the ill and the dying, richly supplemented by particular examples of behaviour and utterances. He assumed the old church sacramental tradition and order. $\mathrm{He}$ also referred to traditional literature for the ill, among others to books on the last four things

40 Cf. ibid, p. 231.

41 Cf. Gustav PIRICH, Franz Giftschütz, pp. 197-198.

42 Cf. Franz GIFTSCHÜTZ, Počátkové, I. díl, p. 238.

43 The prayer of the spiritual shepherd with the dying person was to be concluded with a request for God's help and healing, and also for patience, hope and committing oneself to the hands and will of God. Cf. ibid, pp. 196-197; 224-225; 238.

44 Cf. ibid, pp. 254-255.

45 Cf. Gustav PIRICH, Franz Giftschütr, pp. 196-197. 
of man. ${ }^{46}$ An obligatory topic of spiritual care of the ill was the topic of sin. The individual acts and rituals followed up on one another, in the spirit of the unified teaching each ill and dying person was either to prepare for further Christian virtuous life, or die provided for with the last sacraments. But strong emphasis was also placed on the level of instruction and education. Instruction showed clear Christological motives. The spiritual shepherd came to ill persons with comfort, which consisted primarily in knowing the right concept of illness. In his reasoning the shepherd could make use of so called reasons for comforting the ill, noted already in the first volume of the textbook. ${ }^{47}$ With his attitude he was to bring the ill person to view illness as opportunity and incentive to a more perfect Christian life and also show him corresponding particular manners of acting. ${ }^{48}$

\section{Spiritual shepherd as subject of spiritual care of the ill and the dying}

According to the study texts analysed here all contents of spiritual care of the ill consisted in informed acting and were reserved to the administrator of the spiritual office. In his acting he was bound by the relevant shepherdly norms and behavioural patterns. Of course, in accordance with older recommendations Chládek expressly admitted an exception in his textbook, which however had but limited scope. If the spiritual shepherd was very busy he could authorize other persons, including worldly ones, to perform a visit by the bedside of an ill person in his stead. ${ }^{49}$ However, the spiritual administrator remained the subject of the care in such case as well.

The spiritual shepherd was principally to subordinate his activity to the needs of the ill person and come to visit him as a good friend with advice and help, though unrequested. He was to weigh time properly and not burden the ill person in sleep and pain. It was also not fitting to show signs of fear, on the contrary he was to act bravely, like others who also for love of the neighbour or their country often placed their life in jeopardy. The language of his mouth and body was to radiate calmness, prudence and certainty. At the same time he was to avoid danger and keep in mind that he must maintain his life for himself and his community. That was important from the point of view of the general good, the state and the society. Virtuous life had greater value than useless and imprudent sacrifice caused by lack of knowledge or omitting common means used for protection from the main source of infection, believed to be various infectious vapours..$^{50}$ The spiritual shepherd could learn of examples of these means from the textbook itself, or in greater extent from the cited literature, significantly from protestant milieu..$^{51} \mathrm{~A}$ wise estimation of one's possibilities and

46 The ill person was to turn to spiritual literature primarily as to a means of fortifying piety and using the time of the illness to his benefit. In the spirit of the shepherd's attitude and guidance he was to look for comfort and instruction in it. Among this spiritual literature books on the passion of Christ and on the last four things of man were expressly mentioned. Although the latter were directly related to the other world, the spiritual shepherd did not open this topic himself. Cf. Jiljí CHLÁDEK, Počátkové, II. díl, pp. 156-158.

47 Cf. Jiljí CHLÁDEK, Počátkové, I. díl, pp. 175-177.

48 Cf. Zdeněk DUDA, Nemoc a smrt v opatrné péči osvícenského pastýře, pp. 59-66.

49 Cf. Jiljí CHLÁDEK, Počátkové, II. díl, pp. 153-154.

50 Cf. e.g. Daniela TINKOVÁ, Zákeřná mefitis. Zdravotní policie a veřejná bygiena v pozdně osvícenských Čechách, Praha: Argo, 2012.

51 Means of protection from dangerous vapours were evaporating vinegar, choice of correct place at the head of the ill person, then after the visit a walk in the wind and changing one's clothes. The future spiritual administrators could learn of other suitable means in the book by Pierre Roques on the personality of the evangelical pastor, German translation was cited. Cf. Franz GIFTSCHÜTZ, Poćátkové, I. díl, pp. 236-237. Chládek in his textbook, beside so-called natural means (also with reference to literature), listed also spiritual means, among which he counted prayer, hope and committing oneself to the will of God. Cf. Jiljí CHLÁDEK, Počátkové, II. díl, pp. 155-156. 
time came to the forefront in case of epidemics and the plague, when it was necessary to provide at least the very basic care to the widest possible circle of the ill. At the same time an important task of the spiritual administrator in such situations was to moderate popular imagination, encourage people and generally, as well as by following occasional special ordinances and rules, prevent further spreading of the infection. ${ }^{52}$

Much was expected of the spiritual shepherd in care of the ill, but it was in no way a simple sphere of activity. A number of people did not in fact want his care, they only saw in him an omen and the unavoidability of their end. That is why care of the ill also included effort to change the mind of an important part of the public. Care of the ill thus did not begin with the visit by the bedside of the ill person, but ideally much earlier in the pulpit or somewhere else in another kind of public or private teaching. On the other hand, part of this care was also e.g. to take care of providing for poor orphans. ${ }^{53}$ In caring for the ill the spiritual shepherd was also to take the part not only of healer of souls and expert in religious matters, but of general teacher and advisor, sometimes even in matters of medicine proper, as well as warrantor of public order and hygiene. In all his behaviour he was to be guided by bravery, but also by restraint in gestures and emotions, but most of all by real friendly interest in the good of particular persons as well as the good in general.

\section{Preparation for (a good) death}

Spiritual care of the ill was often part of the care of dying persons. Sometimes the ill person approached death slowly, sometimes abruptly. Different circumstances placed different requirements on the care the person was to receive. The spiritual shepherd was to recognize in what situation the ill person found himself and adjust his activity accordingly. Sometimes several visits were possible, at other times he had to do with only one visit of limited and uncertain duration.

If time was lacking Giftschütz recommended giving the dying person short instruction in basic religious matters. The shepherd was also, as far as possible, to find out the state of the dying person's soul, but not burden him with a complete confession of sins. For the same situation Chládek appealed to the spiritual shepherd to admonish the dying person to confess and persuade him to allow himself be provided for with the last sacraments. If time admitted, he could combine the bidding to penance and confession of sins with an explanation of the beneficence and meaning of confession, or he could also talk him out of prejudice linked to receiving extreme unction. If the dying person had more time the spiritual shepherd was to visit him repeatedly and elaborate the religious instruction bringing tranquillity, comfort and utility for the case of death as well as healing. ${ }^{54}$ This time was also suitable for writing up the testament. Spiritual administrators were to limit themselves to general recommendations, they were to remind the dying of the poor, their participation in creating the testament was considerably restricted by courtly decrees. ${ }^{55}$ In the spirit of his

52 Cf. Franz GIFTSCHÜTZ, Počátkové, I. díl, pp. 255-256.

53 Cf. ibid, p. 240.

54 Cf. ibid, pp. 249-250; Jiljí CHLÁDEK, Počátkové, II. díl, pp. 159-160.

55 Chládek also rejected traditional pious testaments as an abomination and expression of desire for own profit and greed on the part of the clerics. Cf. Jiljí CHLÁDEK, Počátkové, II. díl, pp. 176-178. Giftschütz matter-of-factly recalled courtly ordinances forbidding clerics to write testaments for other persons. Cf. Franz GIFTSCHÜTZ, Počátkové, I. díl, pp. 252-253. 
differentiated attitude and individualized care Giftschütz also specially treated the question how to deal with persons who had endangered their life in an attempt at suicide or the life of another in a duel or fight..$^{56}$

Both pastoralists then obliged the spiritual shepherd to spend the last moments with the dying person and help him commend his soul to God. In order that the dying person not be distracted and burdened by anything, his nearest were to leave the place by the bedside to the cleric and pray for his soul from a distance themselves. Here Giftschütz cited the Viennese diocesan ritual. ${ }^{57}$ Such practice ascribed to the spiritual shepherd the part of an expert on mysterious and other-worldly matters and, despite all effort at change, confirmed him in the role of the messenger of death. Rational argument did not have the power to change the experience of the fascinating and terrifying power of the transition ritual probably most engaged by the human imagination. Chládek's request that the cleric is not the one who first raises the subject of death, ${ }^{58}$ as well as Giftschütz's estimating of the particular situation whether to speak the truth of the approaching death or not, ${ }^{59}$ were in the indicated sense in fact redundant.

In case of death the care of the dying person was concluded by comforting and instructing the bereaved, in case he was cured by encouragement to a new real Christian life. The cured person was to show gratitude to God for the received grace of returned health, remember all the resolutions he had made during the time of the illness and fulfil them. The spiritual administrator was to discern where the healed person was in danger of omitting something and prevent it, e.g. by prescribing an appropriate regime. ${ }^{60}$ The cured person had woken up to a new rationalized life, in which acting was determined by knowledge. To know meant to act properly and then as a result educate others by one's example. The emotional element and always to a great extent unique experience of a significant life situation, which closeness of death without doubt is, were not taken into consideration at all - quite understandably in the Enlightenment context. Even though enlightened spiritual care of the ill was, at least in the textbook of the Viennese pastoralist, considerably individualized, it issued from simple typifications and did not pay heed to internal experience, will and motivation of the object.

56 While the former were to be comforted and the spiritual administrator was to show his compassion and the merciful face of God, the latter were to be blankly reprimanded, shown the ridiculousness of ideas of honour and brought to forgiveness and reconciliation. Cf. Franz GIFTSCHÜTZ, Počátkové, I. díl, pp. 249-250. Chládek differentiates among the dying in the part where he deals with the issue of special aptitude for receiving the sacrament of extreme unction. Cf. Jiljí CHLÁDEK, Počátkové, II. díl, pp. 180-183.

57 Cf. Franz GIFTSCHÜTZ, Počátkové, I. díl, pp. 254-255; Jiljí CHLÁDEK, Počátkové, II. dúl, pp. 179-180.

58 The shepherd was not to hide the danger of death from the ill person, though ideally the first to speak about death were to be relatives or the physician. Cf. Jiljí CHLÁDEK, Počátkové, II. díl, p. 160

59 The shepherd was to do best if he assured the ill person neither of healing nor of death. Giftschütz knew that sometimes it is better to conceal death for a time, at other times to admit it immediately. The shepherd was to be guided by a reading of the particular situation based on three criteria: state of the body and soul of the ill person, his temperament and home specificity. Cf. Franz GIFTSCHÜTZ, Počátkové, I. díl, pp. 251-252.

60 Cf. ibid, pp. 255-256. 


\section{Conclusion}

The reform of theological study carried out under the influence of Jansenist-enlightened ideas in the Danube monarchy in the 1770s brought new views of clerical persons, of whom it strove to make administrators of clerical offices. The study received practical orientation, which was reflected also in the arising of the new discipline of pastoral theology. In it students of theology were systematically prepared for performing spiritual administration, in general for performing the obligation to teach, sanctify and advance piety, of course in the proper contemporary interpretation, which in the religious sphere emphasized the moral area and linked the concept of salvation with the concept of earthly happiness and general welfare. A part of spiritual administration was also spiritual care of the ill and the dying, at the time viewed as one of the most important and at the same time most difficult activities of spiritual administrators. Already Rautenstrauch's obligatory curriculum of the subject of pastoral theology spoke of it in this sense. The first textbooks of the new subject contrived according to the curriculum repeated this view. Spiritual care of the ill and the dying was a novelty at the time; together with the concept of illness as a place of educational processes open to the world it transcended and replaced the traditional Christian preparation for a good death. It was also losing immediate relationship to sacramental practice of the Church, markedly so e.g. in the most successful textbook on the new subject of the time by the Viennese pastoralist Franz Giftschütz. There extreme unction had lost the character of sacrament and ceased to be (a necessary) part of care of dying persons. Such attitude was not unique, but not exclusive either. The several years older Czech-written textbook by Jiljí Chládek described an ideal image of unified care of the ill and the dying, part of which was also the sacramental tradition of the Church and ordering of the last sacraments. The purpose and goal of spiritual care of the ill and the dying was to provide persons in bodily and spiritual need with comfort and instruction, give them peace and calmness and bring them to rectification. This goal was in no way different from the goal of the spiritual administrators' other activities. The means of comfort and instruction was conversation, explanation, as well as prayer, always directed to God, short and intelligible, reflecting the particular situation of the ill person. Emphasis placed on an individualized and differentiated approach to the ill was characteristic and typical especially for Giftschütz's textbook, in the spirit of enlightened anthropocentrism. The form of care of the ill and the dying was to be adapted to the particular situation and derive from the social status, relationship to religion and kind of illness. The only considered subject of this care, as well as of all other pastoral activities, was the administrator of the clerical office. In this role he could be substituted only exceptionally. In his acting he was bound by the relevant norms and patterns of behaviour, which also pertained to language of both the mouth and the body. The parish community was the object of appropriate informed care. In care of the ill and the dying the administrator of the clerical office was to be teacher and comforter, offer instruction bringing utility and joy of virtuous life, become the warrantor of public order and hygiene and be rid of the label of messenger announcing death. That, however, was not easy for him as expert in other-worldly matters and guide through dying. Even in realizing spiritual care of the ill and the dying he was to be, as in all his other activity, guided by true friendly interest in the good of the particular person and the good in general. 


\title{
Spiritual Care of the III and the Dying in First Pastoral Theology Textbooks (Rautenstrauch, Giftschütz, Chládek, Stach)
}

\begin{abstract}
The paper addresses one of the historic forms of pastoral care of the ill and the dying. It focuses on the end of the 18th century, when under the influence of Jansenist-enlightened ideas an important reform of theological study was carried out and pastoral theology was introduced as a university discipline, and when pastoral care of the ill and the dying as spiritual care of the ill came to be presented as one of the most significant and important sphere of the activities of the spiritual shepherd as the only subject of pastoral care. The aim of the paper is to describe the basic points of departure, procedures and form of spiritual care of the ill and the dying, which was as ideal and obligatory presented to future Catholic spiritual administrators as part of university study, based on analysis of the first study texts of the subject of pastoral theology and the context in which they were written. The study is based primarily on two study texts, which received wider use in the Czech milieu.
\end{abstract}

Keywords: pastoral care of the ill and the dying, death, illness, 18th century, Franz Giftchütz, Jiljí (Aegidius) Chládek

\section{Contact}

Mgr. et Mgr. Zdeněk Duda

University of South Bohemia, České Budějovice

Faculty of Theology, Department of Theological Disciplines

Kněžská 8, 37001 České Budějovice

Zdenek.Duda@seznam.cz 